\title{
The Impacts of Organic Pollution on the Hydrochemistry and Community Structure of Benthic Macrofauna of Lagos Lagoon, Southwest Nigeria
}

\author{
*11NKWOJI, JOSEPH AHAMEFULA
}

\author{
Benthic Ecology Unit, Department of Marine Sciences, University of Lagos, Nigeria \\ E-mail: jnkwoji@unilag.edu.ng, josephunilag@gmail.com
}

\begin{abstract}
The Lagos lagoon is a coastal lagoon and hence, is highly impacted by pollutants from anthropogenic sources. The greater percentage of these pollutants is organic in origin. Hydrochemistry and benthic fauna assemblage of five anthropogenically impacted sites of the Lagos lagoon, Nigeria were studied from May to October, 2016 to investigate the effects of organic pollution on them. Water and composite benthic samples were collected monthly at each study station and analysed in the laboratory following standard procedures. The analysis of variance (ANOVA) indicated no significant difference $(\mathrm{p}>0.05)$ in values of the water parameters measured among the study stations. Higher $\mathrm{pH}$ values were recorded at Carter Bridge sampling station and this could be attributed the introduction of carbonates into the water through the washing of cement bags. Salinity of the water was generally low due to the season of the sampling. Introduction of large volumes of biodegradable wastes both reduced the dissolved oxygen level and increased the total suspended solids in the waters of critical sites. A total of 243 benthic macrofauna individuals comprising three Phyla, four Classes, four Orders, eight Families, eight Genera and eight Species were sampled. The gastropods, Pachymelania aurita and Tympanotonus fuscatus dominated the benthic macrofauna assemblage of the study area accounting for $40.3 \%$ and $19.3 \%$ respectively. The relatively low abundance of the filterfeeding bivalves and the highly sensitive arthropod species in the study area may be indicative of organic pollution of the area. CJASEM
\end{abstract}

https://dx.doi.org/10.4314/jasem.v21i2.2

Keywords: Organic; Pollution; Hydrochemistry; Benthic; Macrofauna; Coastal

Pollution of water is a natural or induced change in the quality of water which renders it unusable or dangerous as regards food, human and animal health, industry, and agriculture, fishing, or leisure pursuits. Basically, pollution is induced by those human activities which cause pollutants to enter natural waters. Organic pollution results from the introduction of biodegradable wastes into the aquatic environment in such a level that it interferes with the normal ecosystem functions. It occurs when large quantities of organic compounds, which act as substrates for microorganisms, are released into the aquatic ecosystem. During the decomposition process the dissolved oxygen in the receiving water is depleted greater than it can be replenished, resulting in hypoxia (Nkwoji, 2016) and having severe consequences on the soil, vegetation, organisms and water depending on their density on the biota, (Ribaudo et al. 1999). The use of coastal waters as a repository for anthropogenic waste has not previously been practiced on as large or intense a global scale as in recent decades (Williams, 1996).

There are interactions between physical and biological processes, and between water column and the sediment (Norkko et al., 2002) once pollutants are introduced into the aquatic environment. The benthic macrofauna are at the centre of all these interplays (Nkwoji, 2014). Their sedentary nature makes them the worst hit by pollution. They are therefore widely used as biological indicators. They are commonly used as environmental monitors because they contact with both the water column and the sediment covering the ocean floor and are sensitive to toxic compounds in both (Nkwoji et al., 2016). Benthic macro-invertebrates are useful bioindicators providing a more accurate understanding of changing aquatic conditions than chemical and microbiological data in the water body (Nkwoji and Edokpayi, 2013).

The strategic location of the Lagos lagoon has earned it much research attention and quite a number of published information. Early works on the macrobenthic fauna of the Lagos lagoon were on genus Pachymelania sp. (Oyenekan, 1989) and Neritina sp. (Yoloye and Adegoke, 1977). These molluscan gastropods still persist in the lagoon. Other works on benthic macroinvertebrates include the reproductive and population dynamics of Capitella capitata (Oyenekan, 1988), and the temporal variability of benthic macrofauna of the Lagoon and Harbour (Brown and Oyenekan, 1998). The consequences of pollution on the Lagos lagoon have also been discussed (Ekundayo, 1977).

Ajao and Fagade (1990) worked on the seasonal and spatial distribution of the population of the polychaete, Capitella capitata in Lagos lagoon and 
recorded that the abundance of this polychaete was influenced by sediment type, organic content of the sediment and the sediment metals and hydrocarbon content of the sediment. Edokpayi and Nkwoji (2007) worked on the physico-chemical and macrobenthic invertebrate characteristics of a sewage dumpsite along the bank of Lagos lagoon and recorded a relatively high abundance of the polychaete Nereidae in the station closest to the sewage dump.

The composition, abundance and distribution of benthic macrofauna are influenced by water quality (Odiete, 1999). Sensitivity is commonly expressed as a change in reproduction, growth rate, or mortality, as well as changes in species distribution (Yakub and Ugwumba, 2009; Nkwoji et al., 2010). The aim of the present study is to investigate the effects of organic pollution on some hydrochemical parameters and community structure of benthic macrofauna in Lagos Lagoon, Nigeria.

\section{MATERIALS AND METHOD}

Study area: The Lagos lagoon (Figure 1) is located between latitude $6^{\circ} 26^{\prime}$ and $6^{\circ} 38^{\prime} \mathrm{N}$, longitude $3^{\circ} 23^{\prime}$ and $3^{\circ} 43^{\prime} \mathrm{E}$ and extends eastwards for about $200 \mathrm{~km}$ from the Nigerian-Benin Republic border to the western limit of the Transgressive Mud Coast covering an area of about $208 \mathrm{~km}^{2}$ (FAO, 1969). The Lagos lagoon is the largest of the lagoons in the Barrier Lagoon Complex of the Gulf of Guinea. The lagoon is generally shallow with an average depth of $2 \mathrm{~m}$ but could be deeper in areas of mud and sand mining and shallower in areas of high siltation. Five sampling stations (Table 1) were selected for this study based on their importance as sources of different organic contaminants into the lagoon. The study stretch is about $14 \mathrm{~km}$ in length between Iddo and Ogudu axis of the lagoon. The exact locations of the sampling stations were obtained with the aid of the Global Positioning System (GPS)

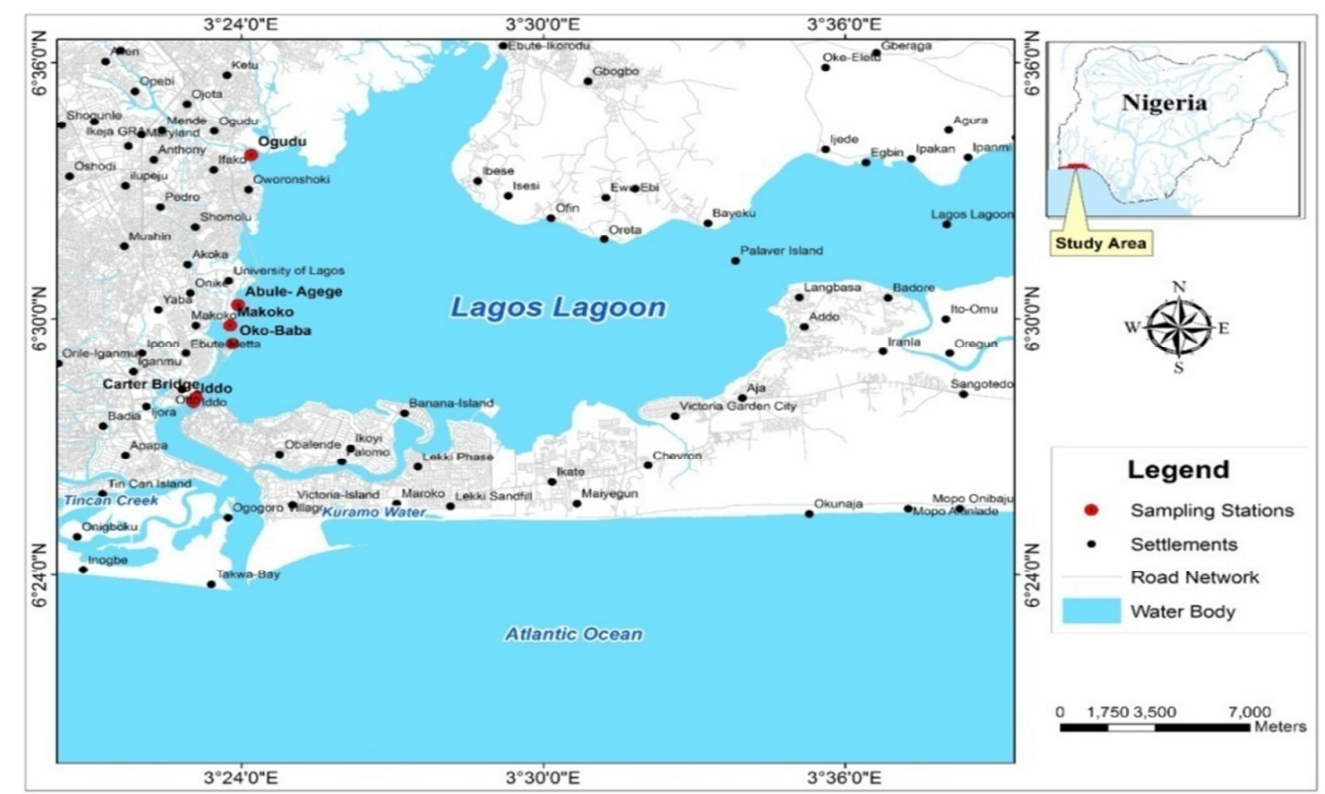

Fig 1: Map of Study Area showing the Sampling Stations

Table 1: Sampling Stations and their Cordinates

\begin{tabular}{llll}
\hline Stations Number & Station Name & Latitude & Longitude \\
\hline 1. & Iddo & $6^{\circ} 28^{\prime} 03.20^{\prime \prime} \mathrm{N}$ & $3^{\circ} 23^{\prime} 02.04^{\prime \prime} \mathrm{E}$ \\
2. & Carter Bridge & $6^{\circ} 28^{\prime} 09.01^{\prime \prime} \mathrm{N}$ & $3^{\circ} 23^{\prime} 05.20^{\prime \prime} \mathrm{E}$ \\
3. & Okobaba & $6^{\circ} 29^{\prime} 25.20^{\prime \prime} \mathrm{N}$ & $3^{\circ} 23^{\prime} 49.02^{\prime \prime} \mathrm{E}$ \\
4. & Makoko & $6^{\circ} 29^{\prime} 51.04^{\prime \prime} \mathrm{N}$ & $3^{\circ} 23^{\prime} 46.39^{\prime \prime} \mathrm{E}$ \\
5. & Abule- Agege & $6^{\circ} 30^{\prime} 19.70^{\prime \prime} \mathrm{N}$ & $3^{\circ} 23^{\prime} 55.80^{\prime \prime} \mathrm{E}$ \\
6. & Ogudu & $6^{\circ} 33^{\prime} 49.09^{\prime \prime} \mathrm{N}$ & $3^{\circ} 24^{\prime} 11.03^{\prime \prime} \mathrm{E}$ \\
\hline
\end{tabular}

Sample Collection and Analysis: Collection and Analysis of Water Samples : Air and Water temperatures, dissolved oxygen (DO) and total dissolved solids (TDS) were measured in-situ at every sampling station with mercury in glass thermometer, hand held LaMotte DO Meter (DO 6 PLUS) and LaMotte TDS Meter (TDS 6 PLUS) respectively. Water samples were collected at stations at sub-surface level in $\mathrm{Idm}^{3}$ sterile capped containers following the methods described by APHA (2005). 
Sampling bottles were kept in large, airtight plastic ice-cold cooler at $4{ }^{\circ} \mathrm{C}$ and were transported to the wet laboratory of the Nigerian Institute for Oceanography and Marine Research (NIOMR), Lagos, Nigeria for analysis. The $\mathrm{pH}$, conductivity and salinity of the water samples were measured in the laboratory with water quality checker (Horiba-U10). Separate water samples were collected in $250 \mathrm{ml}$ dissolved oxygen bottles at each station and incubated in the dark for five days for completion of 5-day biochemical oxygen demand determination as described by APHA (2005).

Collection and Analysis of Benthic Samples: Benthic samples were collected with the use of Van-Veen grab. The sediment samples collected were sieved through $0.5 \mathrm{~mm}$ aperture size sieve. The materials retained on the sieve were stored in plastic container and preserved in 5\% formalin for further analysis. The samples were transported to the Benthic Ecology Laboratory in the Department of Marine Sciences,
University of Lagos for analysis. Sorting of the benthic samples was done with the aid of a hand-held magnifying lens to get the clean samples of the benthic macro fauna. The sorted macrobenthic fauna were identified to species level where possible. They were counted and numbers recorded. Identification was done after Edmunds (1978), Yankson and Kendall (2001).

Benthic Macrofauna Structural Evaluation: The benthic macrofauna structural evaluation will be followed by Margalef's Species Richness Index, Shannon and Wiener Diversity Index, Species Equitability or Evenness Index and Simpson's Dominance Index (Ogbeibu, 2005)

Margalef's Species Richness Index: The Species richness index (d) was calculated using the Margalef's index and used to evaluate the community structure. The equation below was applied and results were recorded to two decimal places.

$\mathrm{d}=\frac{S-1}{\ln N}$

where:

$\mathrm{d}=$ Species richness index

$\mathrm{S}=$ Number of species in a population

$\mathrm{N}=$ Total number of individuals in $\mathrm{S}$ species.

Shannon and Wiener Diversity Index: Shannon and Weiner diversity index $(\mathrm{H})$ is given by the equation:

$\mathrm{Hs}=\Sigma \mathrm{Pi} 1 \mathrm{~Np}$

where

Hs = Diversity Index

$\mathrm{I}=$ Counts denoting the ith species ranging from $1-\mathrm{n}$

$\mathrm{Pi}=$ Proportion that the ith species represents in terms of

numbers of individuals with respect to the total number of individuals in the sampling space as whole.

Species Equitability or Evenness Index: Species evenness or equitability was used to calculate how evenly the species are distributed in a community. It was determined by the equation:

$\mathrm{J}=\frac{H S}{\log 2 S}$

where:

$\mathbf{J}=$ Equitability index

Hs = Shannon and Weiner index

$\mathrm{S}=$ Number of species in a population.

Simpson's Dominance Index (Ogbeibu, 2005)

$\mathrm{C}=\sum\left[\frac{n i}{N}\right]^{2}$

where:

$\mathrm{n}=$ the total number of organisms of a particular species $\mathrm{N}=$ the total number of organisms of all species.

Analysis of Data: SPSS 11.0 Windows application and Microsoft Excel were adopted for the data analyses. Analysis of variance (ANOVA) was calculated for the physicochemistry and the benthic macroinvertebrates across study stations while PAST 
statistical program was used for the computations of biological indices,

\section{RESULTS AND DISCUSSION}

Hydrochemistry: The mean values of the physicochemical parameters in water measured at the study stations during the period of study are shown in Table 2. The highest $\mathrm{pH}$ value (8.2) was recorded at Carter Bridge sampling station and this could be attributed the introduction of carbonates into the water through the washing of cement bags (Plate 1). The low mean salinity level recorded at the study stations during the period of study is due mainly to the fact the study was conducted in the rainy reason (May - October). The analysis of variance (ANOVA) indicated no significant difference $(p>0.05)$ in values of the water parameters measured among the study stations. However, the Post Hoc Tests of Multiple Comparison showed significant difference $(\mathrm{p}<0.05)$ in dissolved values between Abule-Agege and Makoko study stations as well as between Abule-Agege and Iddo study stations. While the Abule-Agege is a relatively less impacted station, Makoko and Iddo study stations are notorious for their high organic wastes. One of the most obvious impacts of organic pollution is the depletion of dissolved oxygen caused by the biodegradation of organic wastes (Nkwoji, 2016).

Run-offs during rainfall bring in particulate matter into the water body. Most of these wastes are biodegradable and would result in the depletion of the dissolved oxygen. In addition to that, these particulate matters increase the total suspended solid content of the water and reduce the transparency and light penetration in the water. The wood wastes dominant at Makoko study station resulted in increase in the total suspended solids (TSS) of the water as well as the total dissolved solids (TDS). While the former may be as a result of the solid wood wastes, the latter could be caused mainly due to the wood exudates. 
Table 2: The Mean \pm SD of the Physico-chemical Parameters of the Water Samples in the Study Area during the Study

\begin{tabular}{|c|c|c|c|c|c|c|c|c|c|c|c|c|}
\hline \multirow[b]{3}{*}{ pH } & \multicolumn{2}{|c|}{ MAKOKO } & \multicolumn{2}{|c|}{ IDDO } & \multicolumn{2}{|c|}{ CARTER-BRIDGE } & \multicolumn{2}{|c|}{ ABULE-AGEGE } & \multicolumn{2}{|c|}{ OKOBABA } & \multicolumn{2}{|c|}{ OGUDU } \\
\hline & RANGE & $\mathrm{MEAN} \pm \mathrm{SD}$ & RANGE & MEAN \pm SD & RANGE & $\mathrm{MEAN} \pm \mathrm{SD}$ & RANGE & MEAN \pm SD & RANGE & $\mathrm{MEAN} \pm \mathrm{SD}$ & RANGE & $\mathrm{MEAN} \pm \mathrm{SD}$ \\
\hline & $6.1-8.10$ & $6.80 \pm .77$ & $6.2-7.4$ & $6.74 \pm .50$ & $6.16-8.20$ & $6.99 \pm .90$ & $6.4-8.20$ & $7.17 \pm .79$ & $6.3-8.4$ & $7.25 \pm .90$ & $6.1-8.20$ & $7.08 \pm .77$ \\
\hline $\begin{array}{l}\text { W. Temp. } \\
\left({ }^{\circ} \mathbf{C}\right)\end{array}$ & $26.0-28.9$ & $27.3 \pm 1.26$ & $26.0-31.0$ & $28.17 \pm 1.1$ & $26.0-30.0$ & $27.7 \pm 1.86$ & $26-31.0$ & $28.2 \pm 2.14$ & $26-31.0$ & $28.2 \pm 2.14$ & $25-30.0$ & $27.2 \pm 1.83$ \\
\hline $\begin{array}{l}\text { Salinity } \\
(\%)\end{array}$ & $0-15.0$ & $4.83 \pm 2.85$ & $0-20.0$ & $7.68 \pm 1.39$ & $0-20.0$ & $7.83 \pm 2.50$ & $0-7.0$ & $2.00 \pm 2.68$ & $0-18.0$ & $4.61 \pm 1.23$ & $0-17.0$ & $3.33 \pm 1.80$ \\
\hline $\begin{array}{l}\text { Conduct } \\
\text { (mS/cm). }\end{array}$ & $1-30$ & $16.7 \pm 12.74$ & $4-31$ & $23.0 \pm 10.4$ & $3-35$ & $23.3 \pm 11.7$ & $1-33$ & $12.3 \pm 1.59$ & $1-38$ & $19.8 \pm 5.87$ & $0-28$ & $8.67 \pm 1.22$ \\
\hline D.O & $4.80-8.80$ & $6.67 \pm 1.43$ & $2.30-7.20$ & $4.48 \pm 1.88$ & $3.00-8.40$ & $5.88 \pm 2.34$ & $6-9.00$ & $7.17 \pm 1.47$ & $2-7$. & $4.83 \pm 2.23$ & $4-7.00$ & $5.83 \pm 1.47$ \\
\hline BOD & $10.4-28.0$ & $18.07 \pm 6.63$ & $13.0-30.0$ & $17.67 \pm 6.1$ & $8.0-30.0$ & $18.7 \pm 8.24$ & $9.0-36.0$ & $16 . \pm 10.33$ & $13-22.0$ & $16.7 \pm 3.61$ & $7-23.0$ & $18.5 \pm 5.85$ \\
\hline $\begin{array}{l}\text { Transp. } \\
\text { (cm) }\end{array}$ & $7.0-36.0$ & $47.90 \pm 9.74$ & $32.5-58.0$ & $52.1 \pm 16.3$ & $32.0-70.0$ & $47.7 \pm 7.31$ & $34-68.0$ & $50.1 \pm 12.0$ & $44.0-68.0$ & $52.0 \pm 9.98$ & $34-62.0$ & $45.3 \pm 11.7$ \\
\hline TDS (g/L) & $\begin{array}{l}1.17-134 \\
15-300\end{array}$ & $28.9 \pm 5.7$ & $\begin{array}{l}1.3-53 \\
17-98\end{array}$ & $17.8 \pm 1.0$ & $\begin{array}{c}0.9-300 \\
11-84\end{array}$ & $56.9 \pm 19.3$ & $\begin{array}{c}0.9-132 \\
10-132\end{array}$ & $29.3 \pm 5.6$ & $\begin{array}{l}1.1-127 \\
7-190\end{array}$ & $28.0 \pm 4.7$ & $\begin{array}{c}1.1-67.5 \\
36-65\end{array}$ & $23.2 \pm 3.4$ \\
\hline $\begin{array}{l}\text { TSS } \\
(\mathrm{mg} / \mathrm{L})\end{array}$ & & $79.50 \pm 11.2$ & & $58.3 \pm 32.1$ & & $50.0 \pm 26.1$ & & $56.3 \pm 43.2$ & & $67.0 \pm 64.1$ & & $50.3 \pm 11.7$ \\
\hline
\end{tabular}




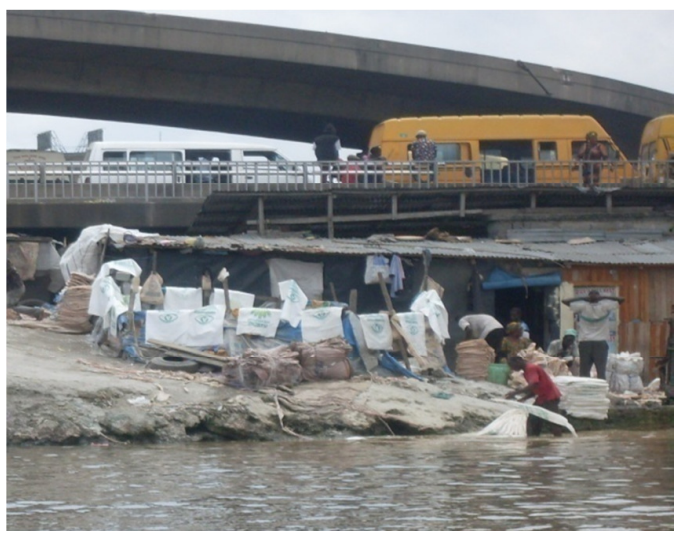

Plate 1: Washing of Cement Bags at Carter Bridge



Plate 2: Logs and Wood Wastes at Makoko Study Station

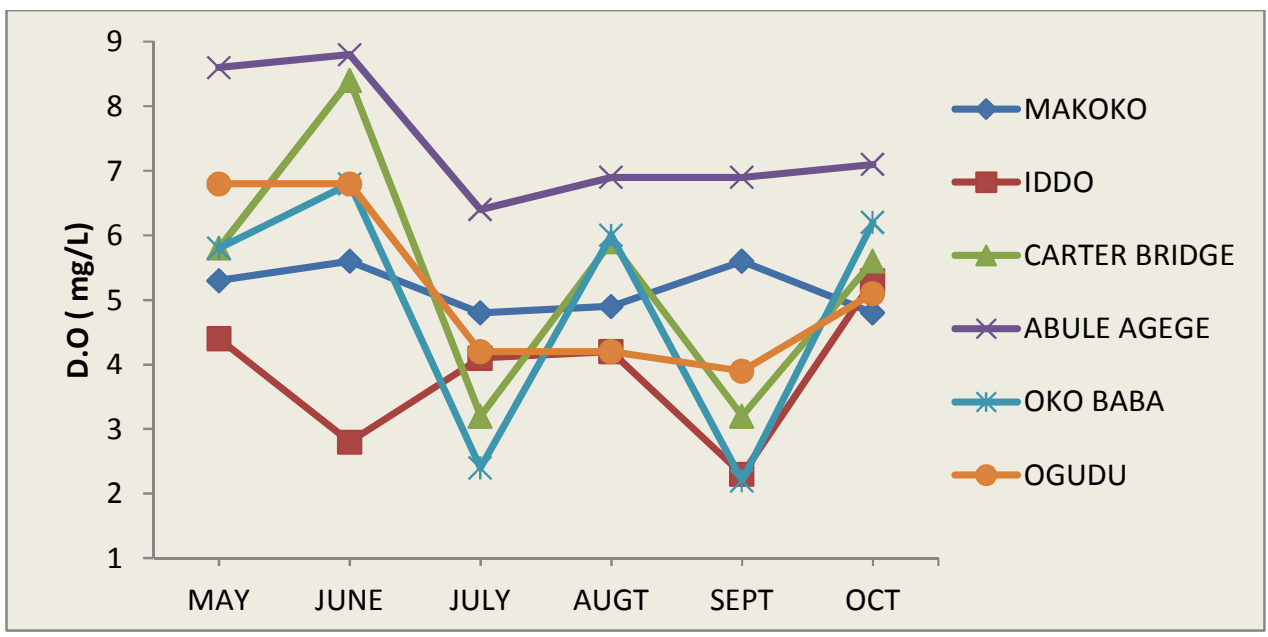

Fig 2: Spatio-temporal Variations in D.O Levels in Waters of the Study Area

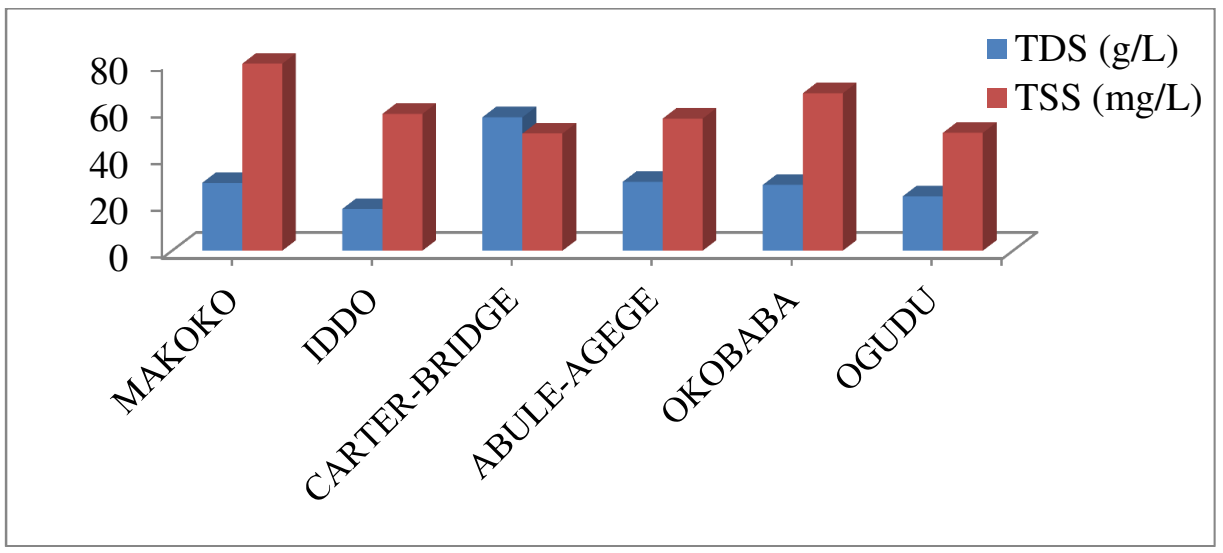

Fig 3: Mean Spatial Variation of TDS and TSS in Waters of the Study Area

Benthic Macrofauna Community Structure: Summary of the spatial abundance of benthic macrofauna of the study area is presented in Table 3. Benthic macrofauna comprising 3 Phyla, 4 Classes, 4 Orders,
8 Families, 8 Genera, 8 Species and 243 individuals were sampled. The phylum mollusca constituted $79.0 \%$ of the total individuals sampled at the study stations for the duration of the study while the phyla 
Annelida and Arthropoda constituted $9.5 \%$ and $11.5 \%$ respectively.

The gastropods, Pachymelania aurita and Tympanotonus fuscatus dominated the benthic macrofauna assemblage of the study area accounting for $40.3 \%$ and $19.3 \%$ respectively. Pachymelania aurita was less spread than Tympanotonus fuscatus. Almost $100 \%$ of it was sampled at the Abule-Agege study station, a relatively unpolluted site. Oyenekan (1989) has identified Pachymelania aurita as a sensitive gastropod. On the other hand, Tympanotonus fuscatus was more widely distributed among the study stations. The high number of Tympanotonus fuscatus recorded in almost all the study stations shows its adaptability and suggests its tolerant nature to habitat modification and organic pollution of the Lagos lagoon.

The percentage contribution of taxa to the overall benthic macroinvertebrates community is presented in Figure 4. The gastropods dominated the macrobenthic fauna in the study area and contributed $67 \%$ of the benthic fauna sampled. The polychaetous annelids recorded the least abundance during the period of study. Nkwoji et al, (2016) however, recorded high number of polychaetes but at the Ondo coastal waters. Earlier works on this part of the lagoon also recorded higher number of polychaetes (Ajao, 1990; Nkwoji et al, 2010; Nkwoji, 2016). The recorded low abundance of the polychaetes in this study may be indicative defaunisation of the benthic fauna in the Lagos lagoon (Edokpayi and Nkwoji, 2007).

Species abundance was highest in Abule-Agege study station and least at Iddo. The Abule-Agege study station has been identified as one of the relatively unpolluted sites in the western part of the Lagos lagoon (Nkwoji et al, 2010; Nkwoji, 2014). This could be attributed to the fact that the station is relatively removed from direct human impact. The Iddo study station on the other hand, was a point source of sewage pollution. Although the station is no longer used as a sewage dumpsite and some sensitive species like the crustacea Sersama huzardii was sampled at the station, the fact that it still has very low diversity and abundance of the benthic macrofauna suggests that the site has not fully recovered from impact of the sewage pollution

Table 3: Spatial Abundance of Benthic Macrofauna of the Study Area

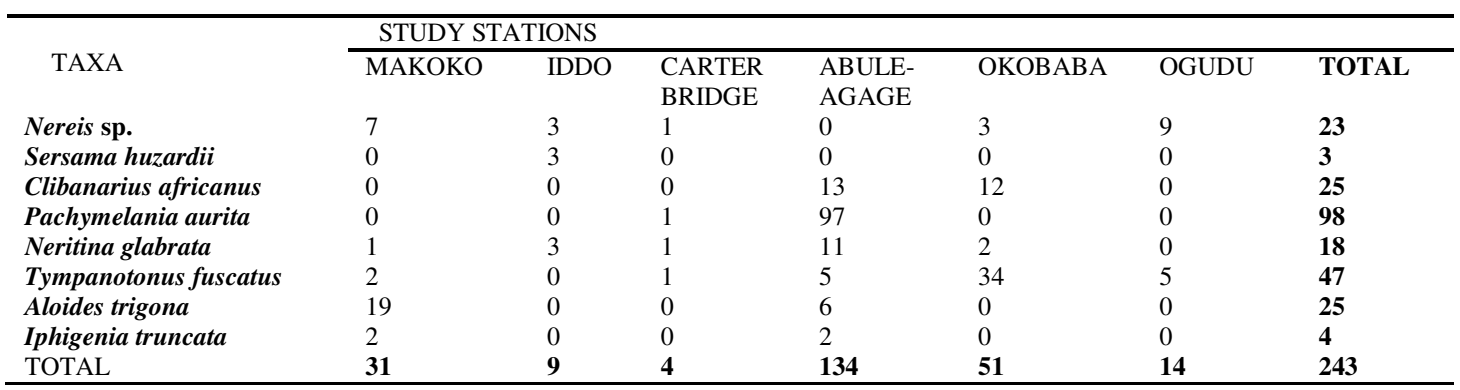

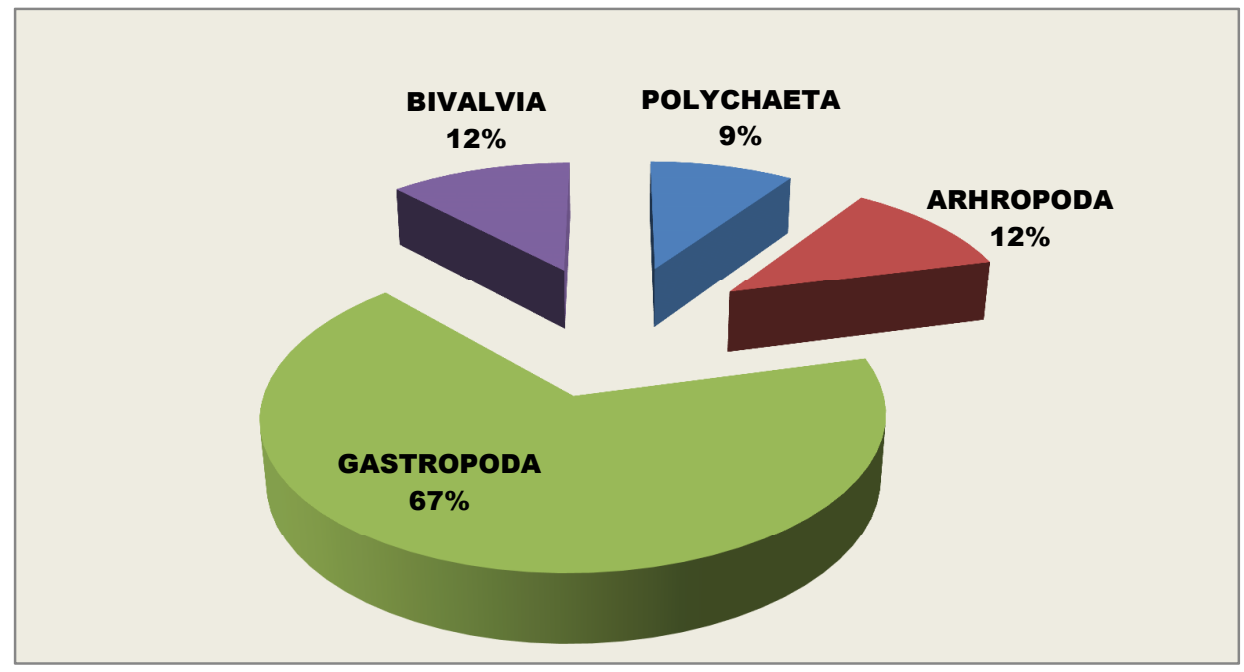

Fig 4: Percentage Taxa Contributions of the Benthic Macrofauna Community 
Table 4: Biodiversity Indices of the Benthic Fauna of the Study Area

\begin{tabular}{|c|c|c|c|c|c|c|}
\hline & MAKOKO & IDDO & CARTER BRIDGE & ABULE-AGEGE & OKOBABA & OGUDU \\
\hline Taxa S & 5 & 3 & 4 & 6 & 4 & 2 \\
\hline Individuals & 31 & 9 & 4 & 134 & 51 & 14 \\
\hline Dominance D & 0.44 & 0.33 & 0.25 & 0.54 & 0.50 & 0.54 \\
\hline Simpson 1-D & 0.6 & 0.67 & 0.75 & 0.46 & 0.50 & 0.46 \\
\hline Evenness $\mathrm{e}^{\wedge} \mathrm{H} / \mathrm{S}$ & 0.6 & 1 & 1 & 0.45 & 0.62 & 0.96 \\
\hline Margalef & 1.2 & 0.91 & 2.16 & 1.02 & 0.76 & 0.38 \\
\hline
\end{tabular}

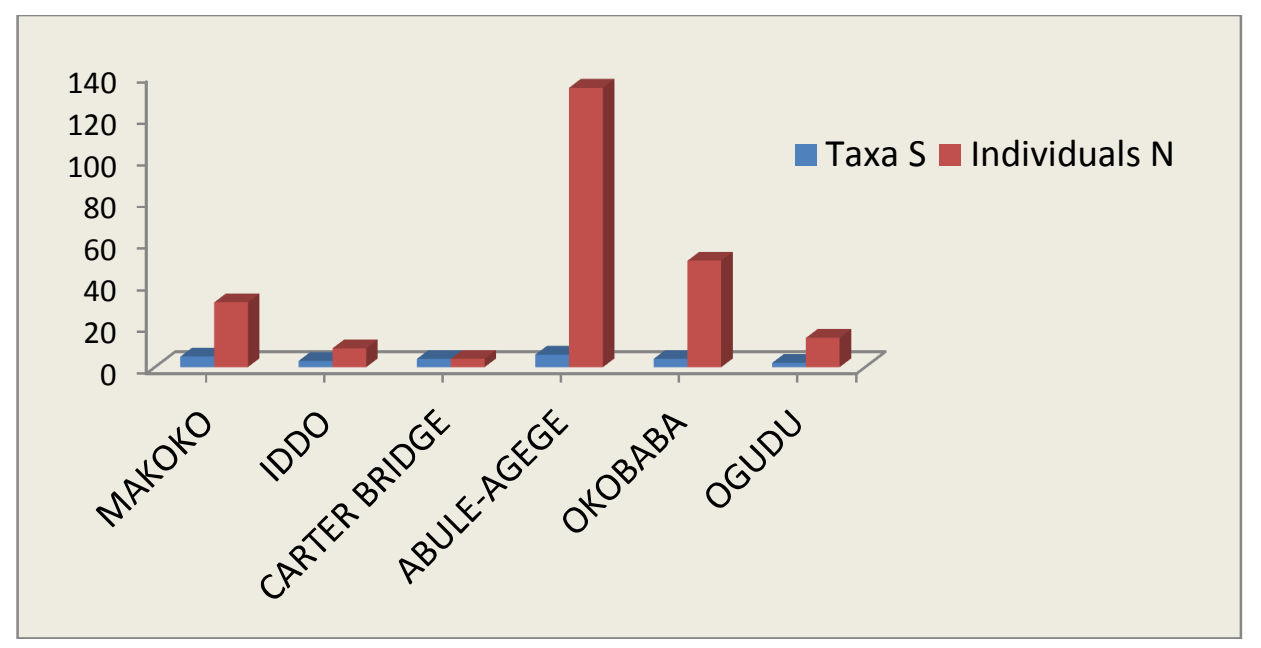

Fig 5: Spatial Variation in the Number of Species and Individuals of the Benthic Macrofauna.

Conclusion: Although some of the physico-chemical parameters of the water of the study area are within desirable limits for aquatic normal life, the relatively low abundance of the filter-feeding bivalves and the highly sensitive arthropod species in the study area may be indicative of organic pollution of the area. Benthic ecologists posit that the community structure of the benthic fauna is a more reliable index for assessing the stability and health of the aquatic ecosystem.

\section{REFERENCES}

Ajao, EA.., Fagade, SO. (1990) The ecology of Capitella capitata in Lagos lagoon, Nigeria. Archive for Hydrobiolog., 120(2): 229-239

Brown AC., Oyenekan JA. (1998). Temporal variability in the structure of benthic macrofauna communities of the Lagos lagoon and harbour, Nigeria. Pol Arch Hydrobiol 45(1): 45 -54p.

Edmunds, J. (1978). Sea Shells and other Molluscs Found on West African Coasts and Estuaries. Accra. Ghana University Press, 146pp.

Edokpayi, CA., Nkwoji, JA. (2007). Annual changes in the physico-chemical and macrobenthic invertebrate characteristics of the Lagos lagoon sewage dump site at Iddo, Southern Nigeria.
Ecology, Environment. and Conservation 13(1): 13-18

Ekundayo, JA. (1977). Environmental consequences of pollution of the Lagos lagoon. Bulletin of Science Association of Nigeria, 3(2): 290-299

F.A.O. (1969) Fisheries Survey in the Western and mid-Western Regions of Nigeria. FAO/sf.74/NIR6. 142pp.

Nkwoji, JA. (2016) Impact of Hypoxia on the Community Structure of Benthic Macroinvertebrates of Lagos Lagoon, Nigeria $J$. Appl. Sci. Environ. Manage. 20(1): 121-130

Nkwoji, JA., Edokpayi, CA. (2013). Hydrochemistry and community structure of benthic macroinvertebrates of Lagos Lagoon, Nigeria. Res. J. Pharm. Biol. Chem. Sci. 4 (1), 1119-1131.

Nkwoji, JA., Yakub, A., Ajani, GE., Balogun, KJ., Renner, KO., Igbo, JK., Ariyo, AA., Bello, BO., 2010. Seasonal variations in the hydrochemistry and benthic macroinvertebrates of a South Western Lagoon, Lagos, Nigeria. J. Am. Sci.6 (3), 85-92. 
Nkwoji, JA., Yakub, AS., Abiodun, AO.., Bello, B. O. (2016). Hydrochemistry and community structure of benthic macroinvertebrates in Ilaje coastal waters, Ondo State, Nigeria Regional Studies in Marine Science 8: 7-13

http://dx.doi.org/10.1016/j.rsma.2016.08.009 23524855/C 2016 Published by Elsevier B.V

Norkko, A., Hewitt, JE., Thrush, SF., Funnell, G.A.( 2002). Benthic-pelagic coupling and suspensionfeeding bivalves: Linking site-specific sediment flux and biodeposition to benthic community structure. Limnol. Oceanogr. 46 (8), 2067-2072.

Odiete, WO. (1999). Environmental Physiology of Animals and Pollution. Diversified Resources Ltd., Lagos, p. 261.

Ogbeibu, AE. (2005). Biostatistics: A practical approach to research and data handling. Mindex Publishing Co. Ltd., Benin, Nigeria. 264pp,

Oyenekan, J.A. (1988). Macrobenthic invertebrates communities of Lagos Lagoon, Nigeria. Nigerian Journal of Sciences. 21: 45 - 51p.
Oyenekan, JA. (1989) The ecology of the genus Pachymelania in Lagos lagoon. Archive for Hydrobiology, 86 (4): 515-522

Ribaudo, MO., RD. Horan; ME. Smith.1999. Economics of water quality protection from nonpoint sources: theory and practice. Agricultural Economic Report No. 782. Economic Research Service, U.S. Department of Agriculture, Washington, D.C., USA.

Williams ,C. (1996). Combatting marine pollution from land-based activities: Australian initiatives. Ocean \& Coastal Management 33(1-3):87-112.

Yankson, K; Kendall, MA. (2001). A student's guide to the seashore of West Africa: Marine biodiversity capacity building in the West African sub-region. 132pp

Yoloye, V; Adegoke, O. S. (1977). A new species of Neritina (Archaeogastroda, Neritidae) from the Lagos lagoon. Malacologia. 16(1): 303 - 309 